\begin{tabular}{|l|c|c|c|r|}
\hline $\begin{array}{l}\text { Cuadernos de Investigación Geográfica } \\
\text { Geographical Research Letters }\end{array}$ & 2018 & N $^{\circ} 44(1)$ & pp.47-67 & $\begin{array}{r}\text { ISSN 0211-6820 } \\
\text { eISSN 1697-9540 }\end{array}$ \\
\hline
\end{tabular}

DOI: http://doi.org/10.18172/cig.3350

\title{
THE LITTLE ICE AGE IN THE TATRA MOUNTAINS
}

\author{
S. KECDZIA*, A. KOTARBA \\ Department of Geoenvironmental Research, Institute of Geography and Spatial Organization, \\ Polish Academy of Sciences, ul. św. Jana 22, 31-018 Kraków, Poland
}

\begin{abstract}
The Little Ice Age (LIA) in the Tatras was characterized by both long and short rainy periods (mostly long cold rainy summers) alternated with warm periods that sometimes were very dry. Definite, precise identification of the onset and ending of the LIA in the Tatras is not possible. Depending on the criteria adopted, the limits of the actual onset and ending vary slightly. During the LIA in the Tatras, there were no fully developed glaciers, and only glacierettes were present. New rock glaciers had not formed while the existing ones did not show any activity. The LIA, in addition to the increased intensity of morphogenic processes, was also reflected in the lives of inhabitants of this part of the Carpathians. For humans the changes were very unfavourable because they were accompanied by a shortened vegetation period and crop yield deficiency that fostered the spread famine and various epidemics.
\end{abstract}

\section{La Pequeña Edad del Hielo en los Montes Tatra}

RESUMEN. La Pequeña Edad del Hielo (PEH) en los montes Tatra se caracterizó por la alternancia de largos y cortos periodos de lluvia (principalmente largos veranos fríos y lluviosos) y por periodos cálidos que a veces fueron muy secos. No ha sido posible identificar el comienzo y el final de la PEH en los Tatra. Dependiendo de los criterios adoptados, los límites del comienzo y el final varían ligeramente. Durante la PEH no se desarrollaron auténticos glaciares en los Tatra, aunque sí pequeños heleros. No se formaron nuevos glaciares rocosos y los existentes no muestran ninguna actividad. La PEH, además de una mayor actividad de los procesos morfogenéticos, se reflejó en las vidas de los habitantes de esta parte de los Cárpatos. Para los humanos, los cambios fueron muy desfavorables porque estuvieron acompañados de un acortamiento del periodo vegetativo y un descenso en la producción de las cosechas que fomentaron la generalización de hambres y epidemias.

Key words: Little Ice Age, Tatra Mountains, climate, glaciers, debris flows, lake sediments. 
Palabras clave: Pequeña Edad del Hielo, Montes Tatra, clima, glaciares, flujos de derrubios, sedimentos lacustres.

Received: 29 June 2017

Accepted: 15 September 2017

*Corresponding author: S. Kędzia, Department of Geoenvironmental Research, Institute of Geography and Spatial Organization, Polish Academy of Sciences, ul. św. Jana 22, 31-018 Kraków, Poland. E-mail address: kedzia@zg.pan.krakow.pl

\section{Introduction}

The term Little Ice Age (LIA) was introduced to earth sciences on the grounds of glaciology by F. Matthews (1939), but its relevance and scope of application changed significantly. It turned out that the increase in the extent of mountain glaciers, observed as the advance of glaciers in the last millennium, was related to climate cooling. Although this cooling was most spectacular in glaciarized high-mountains of the globe, yet its effects have affected vast terrains across the Earth. The resultant major changes in the natural environment have adversely affected the living conditions of people (Maruszczak, 1999). Therefore, the natural and socio-economic changes that took place during this period have become of interest not only to glaciologists. At present, the research is conducted in the field of palaeogeography, palaeohydrology, dendrology and other natural as well as social sciences.

The purpose of this work is to elucidate the question: how did the natural environment of the Tatras, the highest and the northernmost mountain massif in the Carpathians, react to cooling during the LIA, and did the Tatras have got conditions suitable for the re-development of mountain glaciers? Reconstruction of natural processes operating in the Tatras before the man entered there can be done by examining relief forms of slopes and valley bottoms. Determination of the absolute age of these forms is possible with lichenometry, dendrology, dating of organic sediments using ${ }^{14} \mathrm{C}$ radioisotope, and for the last 150 years, also by dating mineral lake deposits with radioisotope ${ }^{210} \mathrm{~Pb}$. The climate changes that have taken place over the past several hundred years have led to changes in the mode and rate of the transformation of mountain relief. The landforms that developed often have been stabilized at present, but in spite of the passage of time they are still fresh, retain their shapes and sizes even though they are relict forms. The lichenometrically dated old slope forms created by episodic high-energy processes are sometimes resistant to later transformations caused by low-energy secular processes. Destruction of records of old high-energy geomorphological events is possible if the landforms formed by such the events become fossilized, i.e. they are buried by younger forms. There are three basic sets of diagnostic slope forms that allow reconstruction of past geomorphological events in the Tatras. These are debris flows, rock fields formed by rock falls and local avalanche relief.

Information on floods, long-lasting precipitation, short-term catastrophic storm rainfalls or thermal anomalies is extremely scarce for the Tatras. Therefore, for the reconstruction of summer temperature for the period 1550-2004, we used available data 
from meteorological stations located around the Tatras as well as dendroclimatic data (Niedźwiedź, 2004; Zielski and Krąpiec, 2004).

There are considerable divergences in views on the beginning and the end of the Little Ice Age. The onset of climate deterioration is determined by the advance of glaciers in the high mountains. However, glaciers reacted variously to climatic changes. The earliest date of onset of the LIA - AD 1200 - was accepted among others by Lowell (2000). Lamb (1977) defined its duration for the years 1550-1850, with the main phase in the years 1550-1700. Historical documents collected in European countries have made it clear that the colder and warmer seasons were nonsimultaneous in the northern hemisphere. However, one can distinguish several cold episodes lasting up to 30 years, which were synchronous on a global scale. Definite global cooling did not always lead to an increase in ice mass. Glaciological reconstructions require simultaneous analysis of thermal and humidity conditions. Luckman (2000) has demonstrated in the Canadian Rockies that the history of changes of glaciers is useful in studying past changes of mountain environments but is not synchronous with historical climate changes. Historical glacier changes must be determined in conjunction with palaeoclimatic conditioning determined by the annual dendroclimatological records, varves, and ice cores. It has been found for the Alps that the response time of glaciers to actual climate changes can be several years or even decades before glaciers reach a new equilibrium (Haeberli and Hoelzle, 1995). The glaciological criterion cannot be a definitive measure of the LIA climate change. Already in 1992, Jones and Bradley (1992) documented the view that there has been no continuous cooling in the past 500 years. Periods of climatic anomalies have occurred at different times in different parts of Europe. Therefore, the reconstructions of climatic, hydrological and geomorphological events in the Tatra Mountains need to refer primarily to regional events.

\section{Natural environment of the Tatra Mountains}

The Tatras are a classic example of high-mountains that are not glaciarized at present. However, they meet the geoecological criteria formulated by Troll (1972). They have got all the formations and deposits associated with erosion and glacial accumulation (Klimaszewski, 1988; Lukniš, 1973). The highest elevated part (the High Tatra) is built of resistant granodiorites and granites. The classic glacial relief has developed there. This relief formed in the Pleistocene, and then in the Holocene it was further developed in two vertical morphogenetic domains - the cryonival (above the upper forest line) and the forest temperate ones. The cryonival domain was free from ice at approximately $12.5 \mathrm{ka}$ (Baumgart-Kotarba and Kotarba, 1995; Makos, 2015), although the final deglaciation of the Tatras took place ca. $8.5 \mathrm{ka}$ (Lindner et al., 2003).

In the cryonival domain the relief is of alpine character. Holocene forms related with frost action and mechanical action of snow and water are transforming glacial slopes and valley bottoms (active cryonival denudation). The temperate forest domain includes areas lying below the timberline. The valley floors, areas of supply of Pleistocene glaciers, are covered with morainic and glaciofluvial mantles. The upper timberline defines the lowest extent of areas regarded as high mountain areas. 
Because of the significant elevation of the Tatras above the sea level (Fig. 1) five geoecologic vertical belts had formed (Hess, 1965). The highest one, named cold- subnival, is located above the orographic snow line (2150-2300 m a.s.l.), where mean annual air temperature (MAAT) is below $-2^{\circ} \mathrm{C}$, and comprises mountain summits and crests. In the belt below, called moderately cold, rocky slopes and rockwalls as well as bottoms of glacial cirques predominate. The lower limit of the next below-lying belt, known as very coolsubalpine zone with dwarf pine, is at the upper forest line (at the northern slopes of the Tatras at $1500-1550 \mathrm{~m}$ a.s.1.). The timberline coincides with MAAT of $+2^{\circ} \mathrm{C}$ and summer (JuneAugust) air temperature of $+10^{\circ} \mathrm{C}$. At Gerlachovsky štit (2655 $\mathrm{m}$ a.s.1.), the highest peak in the Tatras, summer temperature is $8.0^{\circ} \mathrm{C}$ lower than at the upper forest line. Further below there are forest vertical zones. At their foot, at an altitude of about $1000 \mathrm{~m} \mathrm{MAAT} \mathrm{is}+4^{\circ} \mathrm{C}$.

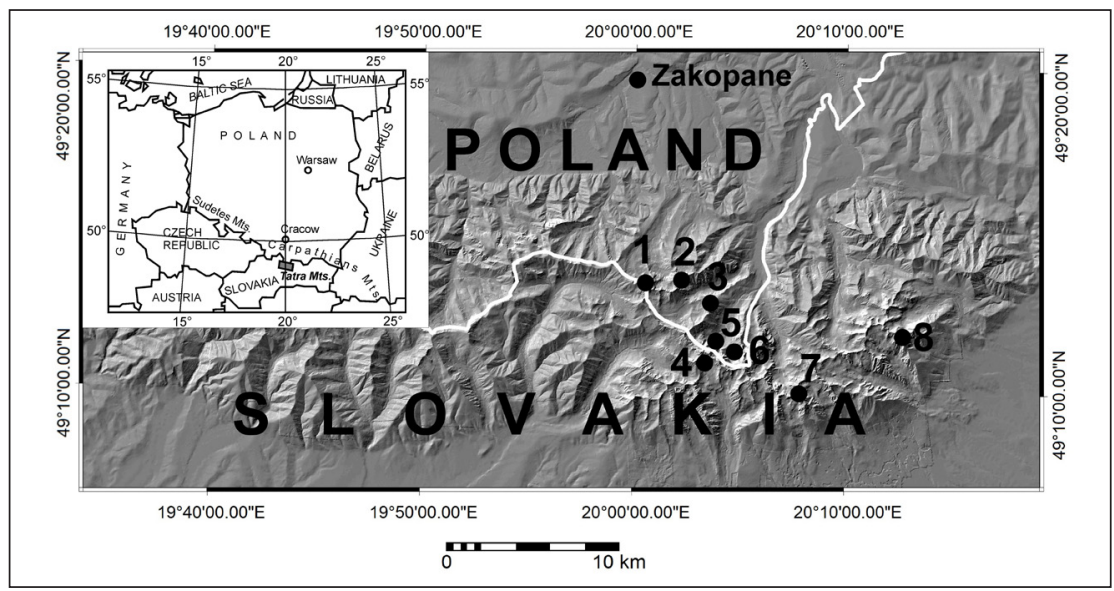

Figure 1. Locations of study areas in the Tatra Mts. 1 - Kasprowy Wierch, 2 - rock glacier in the Buczynowa Valley, 3 - rock glacier in the Świstówka Roztocka valley, 4 - rock glacier in the Mięguszowiecka Valley, 5 - Mięguszowiecki Glacierette, 6 - Morskie Oko, 7 - Gerlachovsky štit, 9 - Lomnicky štit.

Genetically diverse processes modelled the Tatras in different ways. In a vertical profile processes corresponding with climatic differentiation operated. Some processes were limited to one zone, while others covered 2-3 zones (Kotarba et al., 1987). Material that had accumulated at the foot of cirque walls and glacial troughs formed debris slopes that are subjected to further evolution at present. Processes involved here are fast mass movements: rockfalls, avalanches, and debris flows. Present-day debris flows are triggered by rainfalls of $35-40 \mathrm{~mm} / \mathrm{hr}$ or $80-100 \mathrm{~mm}$ per day (Kotarba, 1992, 1995) while a momentary intensity is $1 \mathrm{~mm} / \mathrm{min}$. It can be assumed that at the intensity of $1.0-$ $1.5 \mathrm{~mm} / \mathrm{min}$ just after 15 minutes debris flows can be generated (Kotarba, 1989, 1992, 1995; Gądek et al., 2016). Probability of their occurrence is $10 \%$ (Niedźwiedź, 2003).

The Tatra slopes receive high precipitation in summer season (June-August). Mean annual precipitation varies with elevation above sea level and ranges from 1400 to $1800 \mathrm{~mm}$, with the highest precipitation recorded at altitude of 1500-1900 m (Hess, 1965). At the upper forest limit (station at Hala Gąsienicowa, see Fig. 2) mean precipitation total in summer 
season is $714 \mathrm{~mm}$. Cool years correspond with wet summer seasons (Niedźwiedź, 2004). Debris flows associated with thermal and humidity conditions are dominating geomorphological processes.

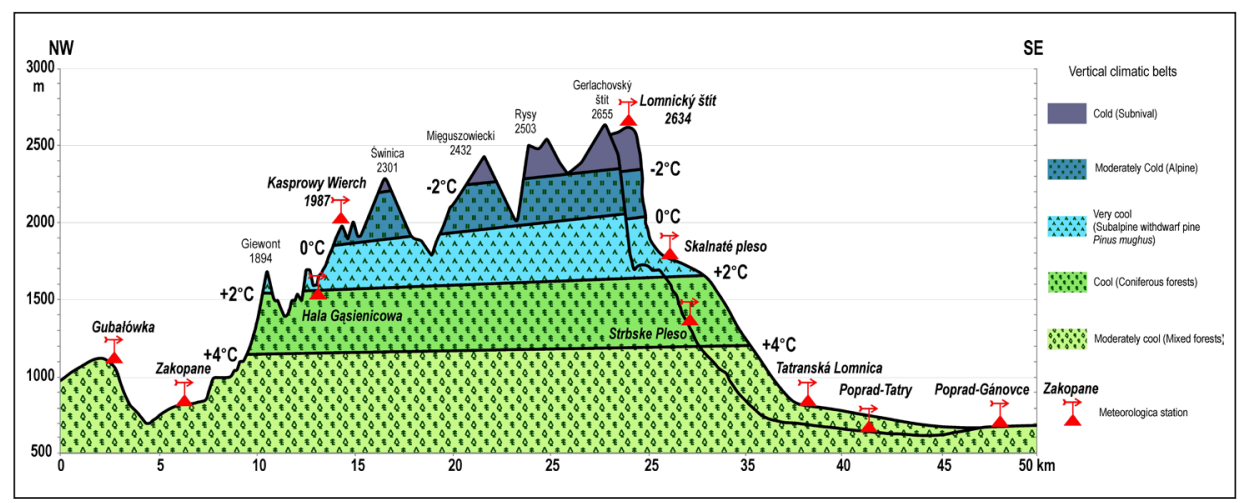

Figure 2. Altitudinal climatic - vegetation - zones after M. Hess (1965) mean annual temperature. Permission from Atlas of the Tatra Mountains, Abiotic Nature 2015, Tatrzański Park Narodowy, Zakopane.

\section{Climate in the Tatras during the LIA}

Niedźwiedź (2004) reconstructed the summer temperature in the Tatras from the year 1550, for the entire LIA period and subsequent current warming (Fig. 3), based on dendroclimatic series form the Alps and the Tatras (Bednarz, 1984). The reconstructed curve refers to the summer temperature at the upper timberline (meteorological station Hala Gąsienicowa $1520 \mathrm{~m}$ a.s.l.). Over the last 466 years, there have been long, cool, and warm periods of more than 100 years with finer fluctuations within them.

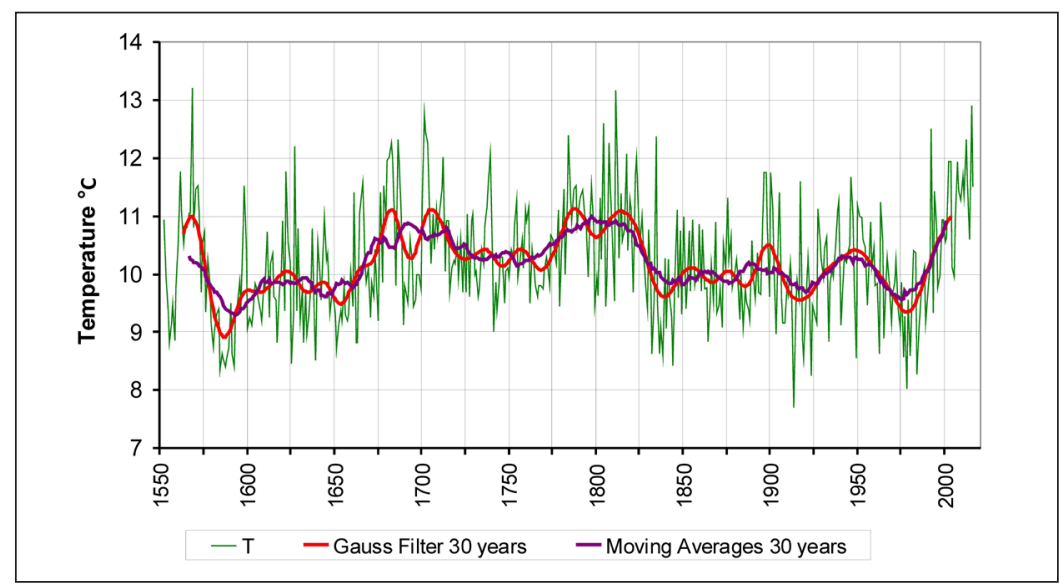

Figure 3. Summer (JJA) Temperature (T) Hala Gqsienicowa 1552-2016 after Niedźwiedź (2004), updated by Niedźwiedź in 2016. 
Distinguished by Niedźwiedź (2004), 102 years, long cold period, lasting from 1576 to 1675 , was also registered in other areas of Central Europe. During this period, high precipitation and related catastrophic floods occurred in Poland. According to Briffa et al. (1998), the summer of 1601 is considered the coldest in Western Europe in the last 600 years. In the foreland of the Tatras summer heavy rainfalls and low air temperature made the harvest of cereals impossible and caused serious economic problems, as the chronicles mention (Siemionow, 1992). In the next warming phase, extreme temperature fluctuations were noted. They were accompanied by numerous floods out of the Tatras (Szaflarski, 1972; Maruszczak, 1999)

The coldest phase occurred at the end of the LIA in the years 1793-1895. It was characterized by cool summers with high precipitation. Particularly cool was the decade 18311840 (Niedźwiedź, 2004). According to Niedźwiedź (2004), the contemporary period that has been lasting since 1896 is very fluctuating, with three warm phases and two cool phases.

In the light of the full reconstruction of the summer temperature (JJA), the year 1576 can be agreed for the beginning of the LIA in the Tatras while the year 1895 for the end. However, setting the temporal limits of the LIA on the basis of summer temperature is not a sufficient condition to distinguish the period and to assess changes occurring in the natural environment of the Tatras. It is important to recognize and determine the age of relict landforms such as debris flows that had developed during extreme hydrometeorological events in the mountain interior as well as to identify extents of snowice patches and lake sediments that had formed during these events. It can be achieved using geomorphological, dendrological, sedimentological and lichenometric methods.

\section{Glaciers}

The period 1830-1890 was the coldest in the Tatras since 1550 (Fig. 3). During this period, there were the greatest advances of Alpine glaciers, which reached their maximum extents on the Holocene scale. The contemporary climatic snow line (cSL) during the warmest decade of the 20th century is accepted in the Tatras at 2500-2600 m a.s.1. During the maximum the LIA descended to 2300-2450 m a.s.1. (Zasadni, Kłapyta, 2009). The relationship between temperature and precipitation (t-p ELA) was taken into account when calculating these heights. These data show that during the maximum cooling of the LIA in the Tatras, despite the lowering of the climatic snow line (cSL), there were no conditions for glaciers to develop in cirques. This view is confirmed by the lack of fresh, i.e. several hundred year old, landforms of glacial origin at the bottoms of the highest elevated cirques. There were no conditions for the development of glaciation during the LIA.

Nevertheless, the largest Tatra glacierette in Medená kotlina was identified by A. Gadomski as "true glacier" in the 1920s. However, its small size reported by that author (Gadomski, 1926a, 1926b) assigns it to a glacierette class rather than to glaciers.

The Mięguszowiecki glacierette is one of the best studied and is located in the Mięguszowiecki cirque in the height range from 1900 to $2040 \mathrm{~m}$ a.s.l. (Figure 4). Its length ranges from 90 to $100 \mathrm{~m}$ while the width from 100 to $150 \mathrm{~m}$. In 1959 Wdowiak counted 126 annual layers in it and estimated the age of the oldest layer at 150 years (Wdowiak, 
1961). Kędzia, when analysing winter precipitation (Jan., Feb., Mar.) and summer air temperatures (Jun., Jul., Aug.) in Zakopane, assigned formation ages to some layers of this glacierette (Figs. 5 and 6). The thick annual layers were characteristic of the years in which winters were very snowy and summers were cool. Particular attention in the drawing of Wdowiak deserves the layers from the first decade of the 20th century and the second half of the 19th century, which despite the compression were characterized by large thicknesses. Considering Alpine glaciers, Vivian (1975) reports the years 1880-1894 and 1914-1925 as periods of glaciers advancements. Taking into account that the response time of glaciers to periodic climate changes is significantly longer than the response time of glacierettes, there is a strong correspondence between the Mięguszowiecki Glacierette and the Alpine glaciers. At the beginning of the 1970s S. Kędzia during the study of the Mięguszowiecki Glacierette did not count so many layers (Kędzia, 1993). In later years, ablation of this glacierette was even greater and the number of annual layers decreased to a few (Gądek, 2002; Wiśliński, 2002). In 2012 S. Kędzia dated thalli of lichen Rhizocarpon geographicum on the rock wall adjacent to the glacierette (Fig. 4) and evidenced that the Mięguszowiecki Glacierette was thickest about ca. mid-19th century. The glacierette in its mid-section was about $10 \mathrm{~m}$ thicker than it is now. Datings of the thalli on the nearby protalus rampart and nival moraine showed that in response to climatic changes the glacierette mostly changed its thickness. The length and width of the glacierette fluctuated in a much smaller range. The age of maxim thickness determined this way can be related to the mid-19th century, when many Alpine glaciers showed the greatest advances (i.a. Vivian, 1975; Bachmann, 1979; Röthlisberger et al., 1980; Zumbühl et al., 1983). The study by Kędzia (2015) confirms the earlier thesis of Jania (1997) that there were no fully developed glaciers in the Tatra in the LIA.

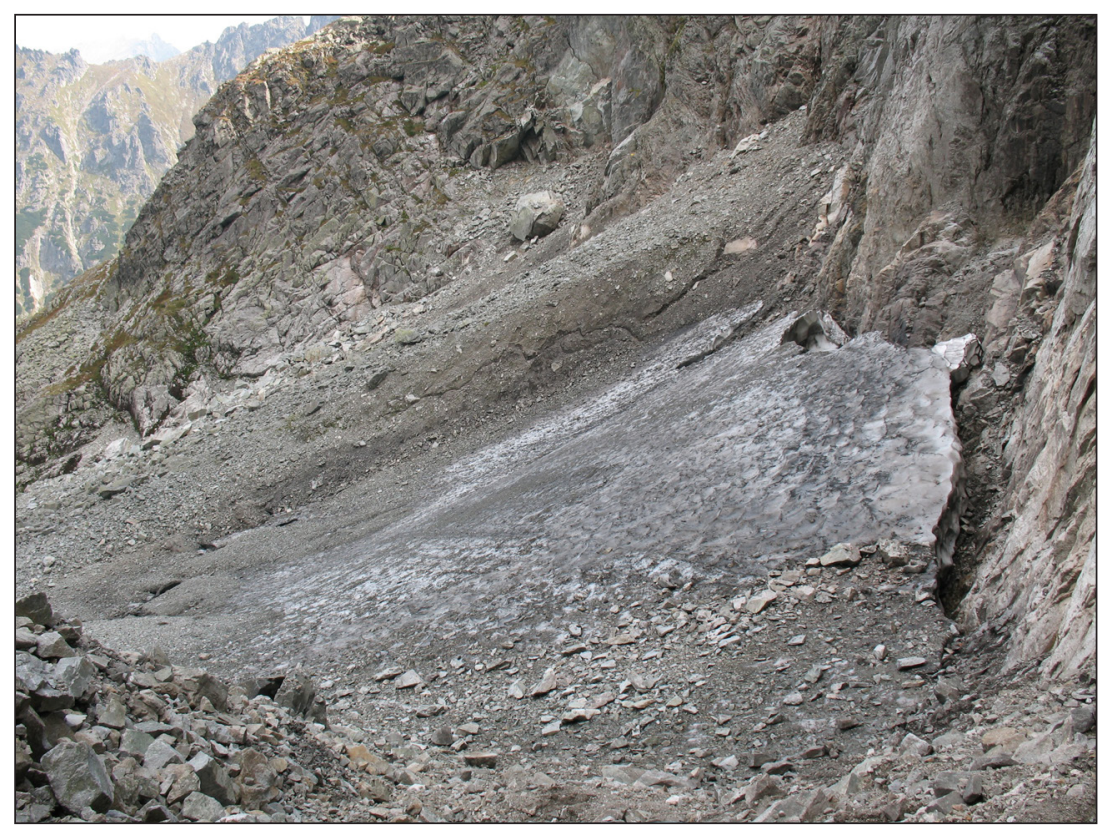

Figure 4. Mięguszowiecki Glacierette. Photos: S. Kędzia (12 Sept.2012) 


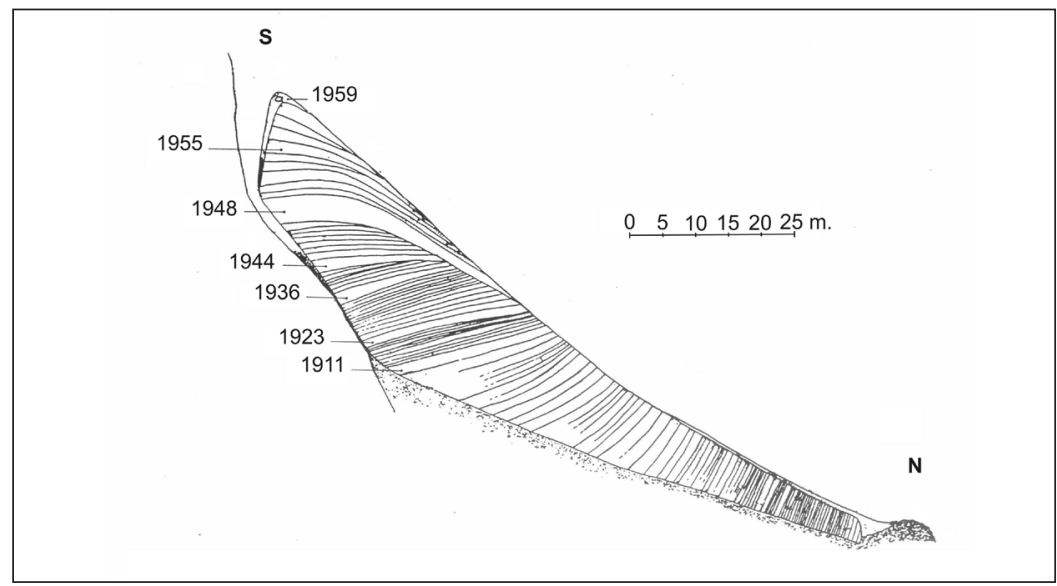

Figure 5. Mięguszowiecki Glacierette with annual layers marked by Wdowiak in 1959, with dating attributed to certain layers by Kędzia (Kędzia, 2015).

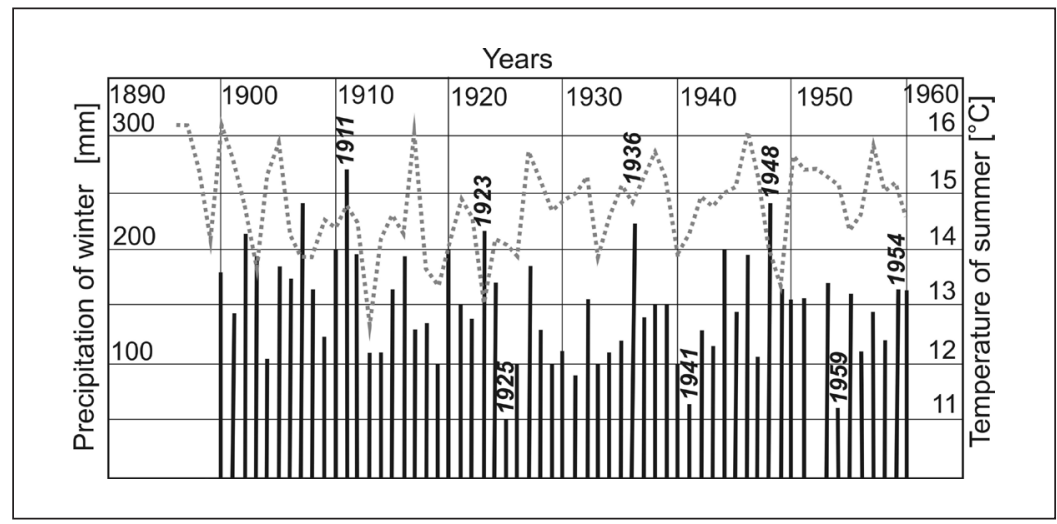

Figure 6. Summer temperature (Jun. - Aug.) and winter precipitation (Jan. - Mar.) at the weather station in Zakopane with highlighted dates attributed to the selected annual layers of the Mięguszowiecki Glacierette (Kędzia, 2015).

\section{Rock glaciers}

In the Tatras several dozen forms have been classed as rock glaciers. The most extensive forms of over $1 \mathrm{~km}$ long are found in the western part of the Tatras (Nemčok and Mahr, 1974; Kotarba, 1986, 1988, 1991-1992). The authors in majority put forward that the rock glaciers in the discussed mountain massif were formed during the Younger Dryas or earlier, and are most often associated with a melting of the Würm glaciers (Klimaszewski, 1948, 1988; Jahn, 1958; Kotarba, 1986; Kaszowski et al., 1988; Kłapyta, 2011, 2013). Geophysical studies by Dobiński (1997), Gądek and Kędzia (2008, 2009) and Kędzia et al. (2004) show that some rock glaciers may contain permafrost in form of small ice lenses. 
Because some authors believed that several rock glaciers could have formed during the LIA period (Dzierżek and Nitychoruk, 1986; Dzierżek et al., 1987) and may continue to move due to permafrost (Ciepły, 2011), Kędzia (2014) carried his lichenometric study on rock glaciers in the Świstówka Roztocka and Buczynowa valleys. The largest measured thalli Rhizocarpon species were ca. 400 years old. However, this is not the maximum age, only the minimum, as nowadays the thallii growing over the boulders of the rock glaciers are next generations of the thalli. The largest thalli were not the oldest tissues of living lichens, only the oldest which met lichenometric dating requirements. This means that for at least 400 years the studied rock glaciers have shown no movement characteristic of this type of active forms. Even the older thalli, aged ca. 500 years, were measured on the rock glacier that was studied a dozen years ago in the Mengusovská valley (Fig. 7).

Lichenometric dating showed that Tatra rock glaciers were formed before the LIA. Unfortunately, due to the relatively fast growth of the thalli, it is not possible, however, to determine the exact time interval of their emergence. Most likely the rock glaciers started to develop, as most authors claim, at the turn of the Pleistocene and Holocene. Some of the rock glaciers could have been still active or even formed in the Venediger period when the last cirque glaciers located at high elevation melted (Baumgart-Kotarba and Kotarba, 2001a, 2001b).

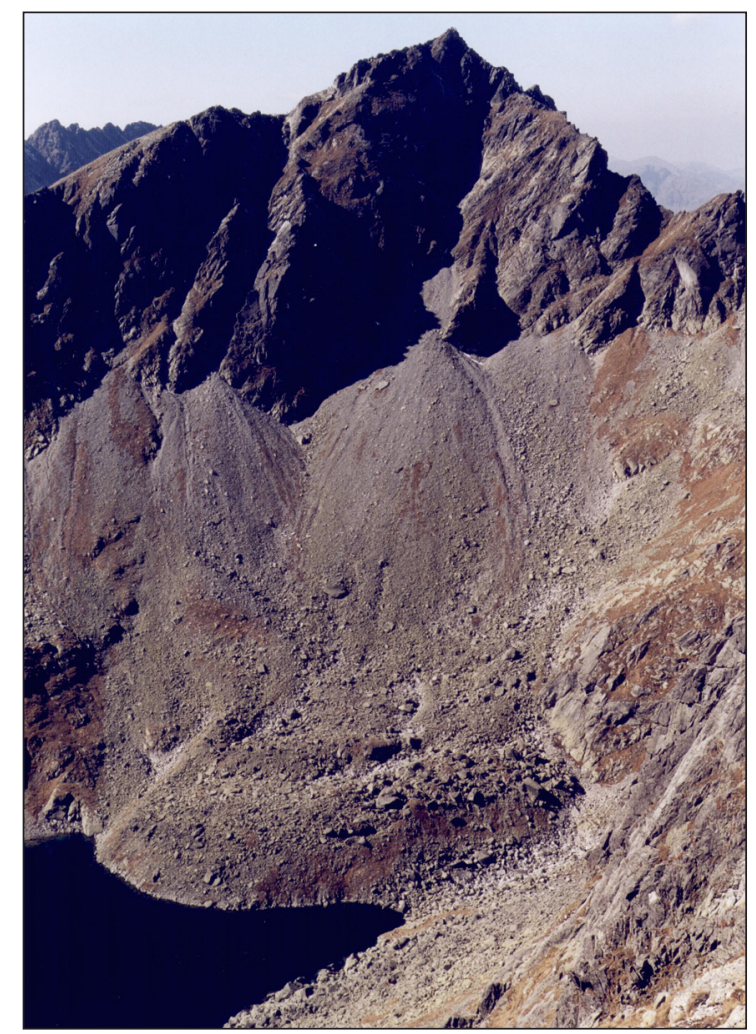

Figure 7. Rock glacier in Mengusovská Valley. Photos: J.W. Mościcki. 


\section{Ice in caves and permafrost}

In the Polish part of the Tatras, there are 30 caves in which snow and ice occur perennially. Most of them are in the elevation range of 1450-1800 $\mathrm{m}$ a.s.l. The amount of snow and ice occurring in the caves is constantly fluctuating, not only annually, but also for many years (Zwolinski, 1961; Siarzewski, 1996). One of the best explored ice caves in the Polish part of the Tatras is the Lodowa (Ice) Cave, situated at $1715 \mathrm{~m}$ a.s.l. on the slopes of the Ciemniak summit. Zwolinski in 1933 counted there more than 400 layers of annual ice, which means that ice accumulation in the cave began at least at the beginning of the 15th century (Zwoliński, 1961). This author, on the basis of nearly forty years (1922-1960) observations, found a systematic decrease of ice thickness in the cave. This process has intensified for the last 20 years of observation. According to Zwoliński the greatest impact on the decrease of ice in the cave is climate warming after the LIA.

In the Tatras, in addition to ice in the caves, there is also present permafrost of cryogenic and glacigenic origins (i.e. Dec and Dobiński, 1997; Dobiński, 1997, 2011; Mościcki and Kędzia, 2001; Kędzia, 2004; Gądek and Grabiec, 2008; Gądek et al., 2009; Gądek and Kędzia, 2009). Although the studies on permafrost by modern methods are being carried out for over 20 years, it is still difficult to say with any certainty whether the recorded increasing trend in bottom temperature of snow (BTS) continues from the end of the LIA, or whether it is only a periodic fluctuation (Kędzia et al., 1998; Gądek et al., 2009; Mościcki, 2010). Taking into account historical records of summer temperatures in the Tatras (Krzemieniowski, 1903; Sokołowski, 1928; Siemionow, 1992) and the studies of Niedźwiedź (Fig. 3) as well as the cave ice behaviour, it is very probable that during the LIA (or at least in its coldest periods) the permafrost covered more area than today. Perhaps, also the currently inactive patterned grounds, which are considered of Pleistocene origin, were still active in the LIA. On the other hand, as the rock glaciers were not moving for at least 400 years, the increase of the surface area occupied by the permafrost in the LIA had not must be many times larger than it is nowadays.

\section{Debris flows as a source of information on climatic changes for LIA}

During geomorphological studies in the very cool climatic belt, i.a. on the debris slopes near Czarny Staw Gąsienicowy lake in the High Tatra at the height range of 1550-1850 $\mathrm{m}$ a.s.1., classic levees, chutes and tongues of morphologic forms produced by debris flows were mapped and levelling survey was executed across glacial cirques, and finally age of these forms was determined by lichenometry. It was found that the oldest debris flows, older than 100 years, reached the foot of the slopes, depositing material transported from higher positions in the form of tongues and levees. Sporadically, younger debris series are inserted here by flows that formed during the past 30-40 years. Over 100 year old tracks of the debris flows were 10-20 m wide while these younger than 100 years did not exceed $10 \mathrm{~m}$ in width (Fig. 8). Also measurements of the maximum grain-size of material forming the levee-type forms shows that the over 100 year old forms are characterized by numerous blocks with long axes ( $a$ axes) exceeding $100 \mathrm{~cm}$, and in extreme cases reaching up to $170 \mathrm{~cm}$ (Fig. 8). These observations allow us to assume that the transport capacity of the waters 
flowing down the slopes in the final period of the LIA was greater than at present. The maximum block fraction indicates the grater competence of these waters. The size of the largest blocks entrained in debris flows is an indirect measure of the intensity of the hydrological phenomena causing the formation of debris flows. At present at the foot of rock walls, the hillslope debris flows which form over the entire lengths of slopes come into being occasionally, and it happens only during summer convectional downpours which probability is just $1-5 \%$. Then, the debris flows of the sizes similar to those that are characteristic of the LIA may be formed (Kotarba, 1992). An analysis of old and modern tracks of debris flows in the Slovak part of the Tatras has prompted Midriak (1985) to express the view that in the past, under the severer climate regime, the forms were larger, longer and descended much lower than at present. Very high activity of slope processes, including debris flows, was characteristic of the final phase of the LIA, especially the periods of 1820-1830, 1850-1860, 1880-1900 and 1910-1920 (Kotarba and Strömquist, 1984; Kotarba, 1995, 2004; Gądek et al., 2010, 2016; Kędzia, 2010). The frequency of debris flow events varies greatly from area to area, but dated track sediments suggest that majority of substantial tracks were triggered in the period 1800-1870 (Fig. 8).

After the LIA had ceased, there was a period of relative stabilization of slopes. The increased activity of the debris flows occurred again in the 1930s and 1940s but it was much less intense than during the LIA (Kotarba and Strömquist, 1984) (Fig. 9). The next period was characterized by the re-stabilization of debris slopes, which lasted until the 1960s. Since the seventies of the last century, the activity of debris flows has increased significantly, however, it does not match that of the LIA.

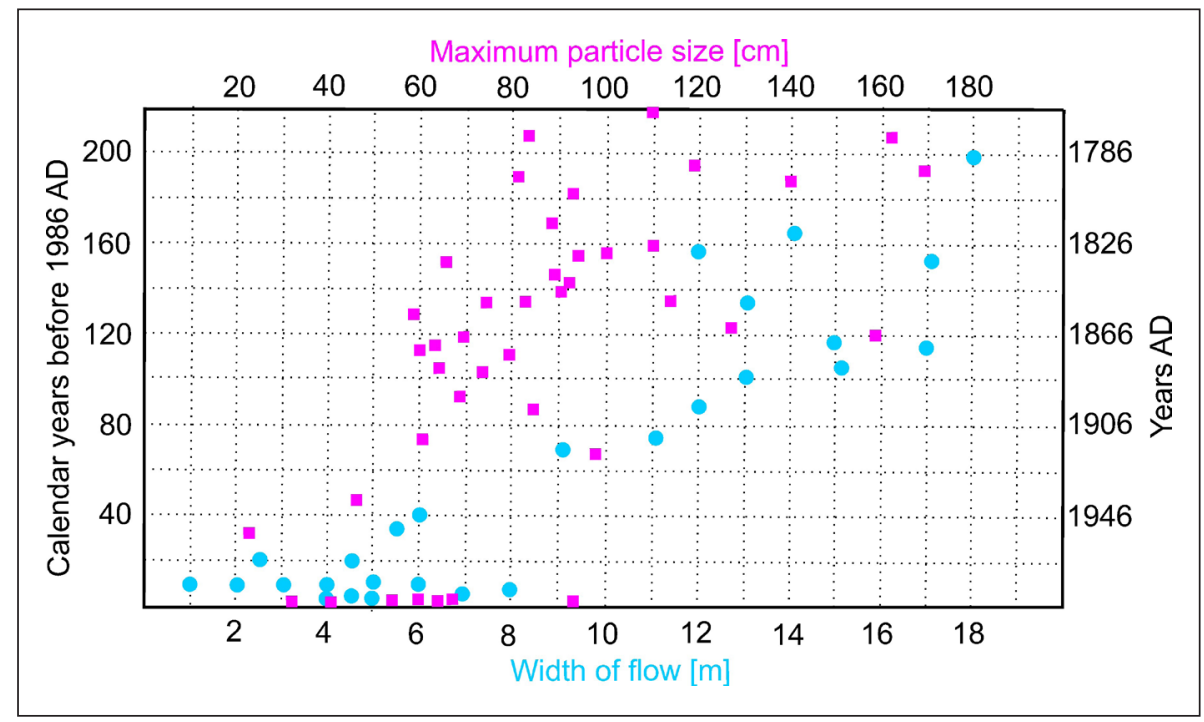

Figure 8. Maximum boulder size (magenta color) deposited in levees of debris flow tracks, and maximum width of hillslope debris flow tracks (blue color) triggered during last ca. 220 years (lichenometric dating) at Gqsienicowa Valley (after A. Kotarba, 1992). 


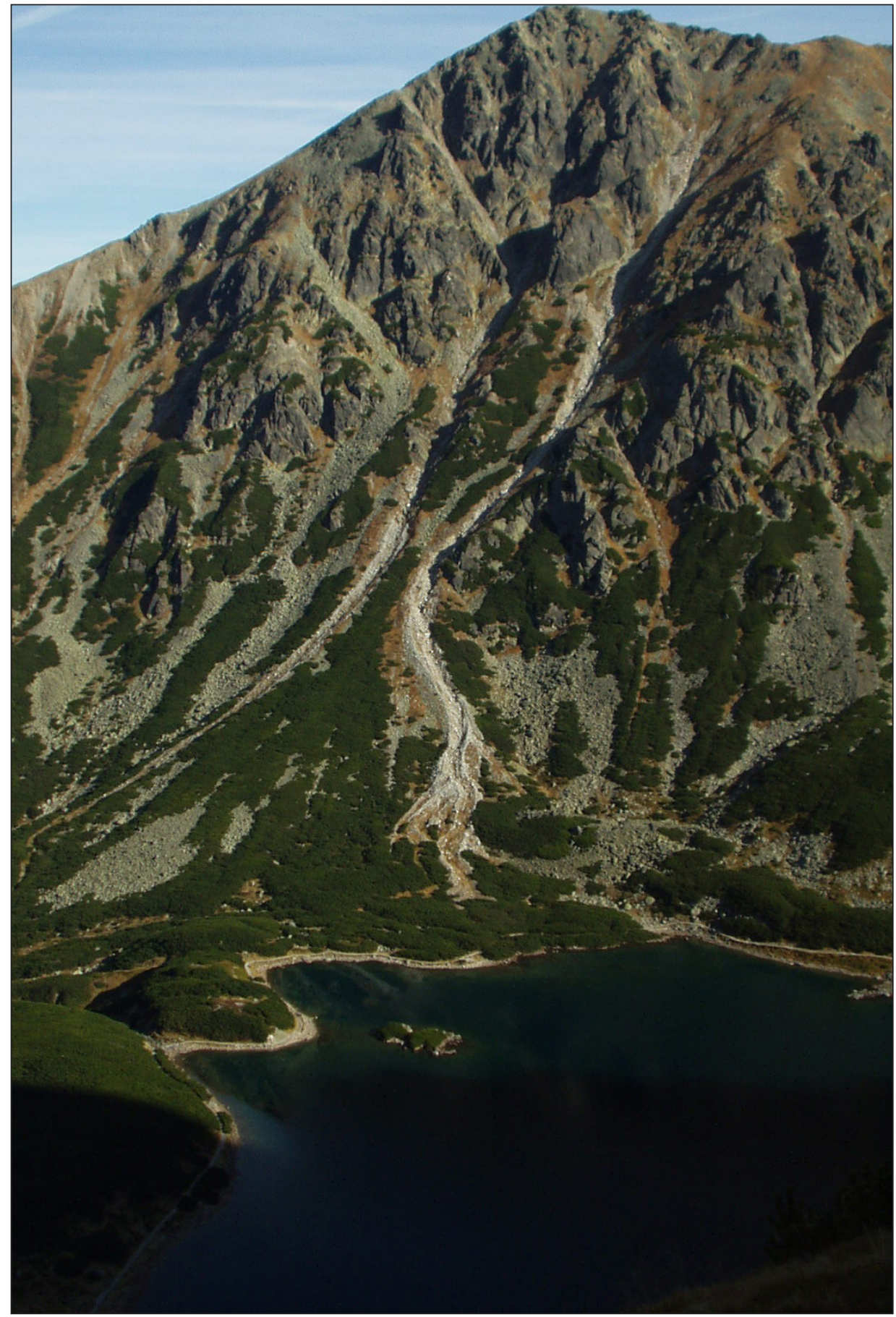

Figure 9. Debris flows on the slope on Żótta Turnia Mt. Photos: S. Kędzia. 


\section{Lake sediments}

For the reconstruction of geomorphological events that had occurred during the LIA, sediment loads deposited in tarns were used. The sediment cores were collected from Tatra lakes by using a gravity corer developed at the Institute of Physical Geography of Uppsala University (Axelsson and Håkansson, 1972).

The technique was especially valuable when studying the uppermost, often very soft part of the deposits, and X-ray radiography of sediment cores reveal the vertical bulk density variation and the structures of layers. Layers recognized within the cores were investigated in term of loss of ignition $\left(450^{\circ} \mathrm{C}\right)$ and grain-size composition. Summary of the results of lake sediment investigations carried out within the PolishSwedish join research programme was published by Baumgart-Kotarba et al. (1990) and Jonasson (1991).

When there is direct contact of talus slopes with lake basins, geomorphic events bring sediment into the lakes. Present-day permanent streams entering Tatra lakes are free of suspended matter. Sediment supply to the lakes is controlled by active debris slopes that are in connection with the lakes. Therefore, a significant component of sedimentary record is related to episodic extreme events on slopes, first of all, debris flow activity. The structure of these sediments allows us to infer the nature of the slope processes. The higher-energy the processes, the more materials are delivered to the lake and the coarser-grained material predominates in the grain-size composition. The materials transported by debris flows, dirty snow avalanches and rockfalls which enter lakes are deposited on underwater basin sides (slopes) while the finer fractions are transferred by turbidity currents to flat bottoms of the basins and deposited there as mineral varved deposits. The sediments of the flat bottoms of the lake basins are records of the events that delivered slope materials to the lakes. On X-radiographs of the bottom sediments, mineralogical laminae are recoded as light bands. They are altered with dark gyttja enriched with organic matter that was deposited in "calm" periods, i.e. in periods with no high-energy geomorphological processes on slopes surrounding the lake. The structure of ${ }^{14} \mathrm{C}$ and ${ }^{210} \mathrm{~Pb}$ dated sediments of the central part of Morskie Oko lake is presented in Figure 10. In fine laminated sediments dated at the turn of the LIA rock pieces -dropstones- are identified. They evidence the role of snow avalanches in transportation of material from the slopes even to the places most remote from the lakeshores. The sedimentary structures allow deduce the onset of the LIA around AD1400 and its ending around 1860, albeit the light mineralogical laminae are also visible in younger sediments (Post-LIA on Fig. 10). Sandy and sandy-silty laminae are of high density. The youngest sediments with the highest content of organic matter (post LIA) are dark on X-radiographs while mineral laminae within them are relatively few. 


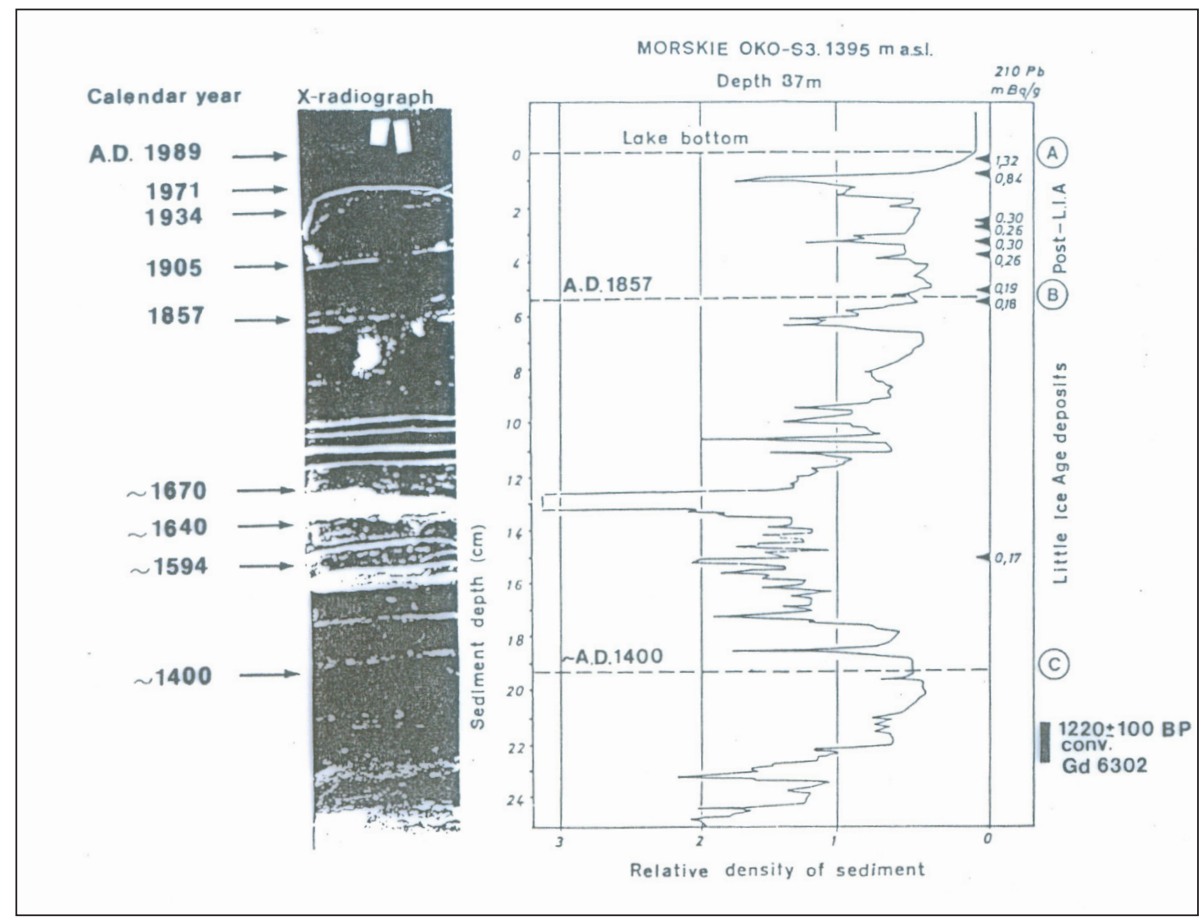

Figure 10. X-radiograph of sediment core, densitometric curve and dating by radioisotope ${ }^{210} \mathrm{~Pb}$ from Morskie Oko lake. Letters mark location of actual lake bottom (A), limit of sediment formed during the Little Ice Age (B), and approximate limit of the beginning of LIA sedimentation (after A. Kotarba, 1995; Kotarba et al., 2002).

\section{Timberline}

The course of the timberline in the Tatras has been disturbed by humans for centuries. Mining and metallurgy fostered the largest damage to natural tree stand in the Tatras. Although the beginning of ore excavation in the Tatras goes back to a remote past, the beginning of intensive excavations can be attributed to the 15 th century. On the other hand, the most burdening forest exploitation for the needs of metallurgy and mining took place in the second half of the 18th century and the first half of the 19th century. At the end of the 19th century, the mining and metallurgy in the Tatras began to decline (Szaflarski, 1972). Unfortunately, the upper limit of the forest was still disturbed by excessive grazing of sheep and cattle. In the 1970s pastoral activities in the Tatras were first suspended and then restored in a very limited form (Ladygin, 2008). Because the upper timberline in the Tatras was lowered by man not only during the whole LIA but also for about half a century after its ceasing, it is difficult to clearly conclude how climatic changes during the LIA affected the actual position of the timberline. According to Sokołowski (1928) the timberline in the highest parts of the Tatras was subjected to the smallest 
anthropogenic disturbances. In the mid-1920s, just after the ceasing of the LIA, in the Sucha Woda Valley, Sokołowski recorded the highest located upper forest line on the northern slopes of Żółta Turnia at the elevation of about $1560 \mathrm{~m}$. After the pastoral activity was withdrawn from the aforementioned valley, the upper forest line started to rise. In 2009, J. Baranowski and S. Kędzia reported the discussed forest limit on the northern slopes of the Żółta Turnia is at the same height as noted by Sokołowski (Baranowski and Kędzia, 2010). Also in other places in the upper part of the Sucha Woda Valley the upper limit of the forest did not exceed the height of about $1560 \mathrm{~m}$. It can be hypothesized that the upper forest limit in the Tatras rises in places where it was lowered by man, but where its course was not subject to anthropogenic influence, the border did not change its position. This means that the LIA climatic changes had little effect on the timberline in the Tatras.

\section{LIA and man}

Man has been exploiting the natural resources of the Tatras for centuries. In addition to the ore, these mountains provided the local population with wood for the construction of houses and for fuel. Tatric meadows and pastures provided feed for sheep, cows and horses. Climatic changes in the LIA had a great impact not only on the natural environment of the Tatras, but also on the standard of living of the people inhabiting the foothills. Unfortunately, the LIA was very unfavorable as reported in the Tatra chronicles. Most information about the impact of the LIA on the lives of Tatra mountain-people is provided by Christian Genersich and Father Józef Stolarczyk (Siemionow, 1992). The 17th and 19th centuries were particularly burdensome to the locals. Cold and rainy summers caused crop failures. The growing grain was infected. Long-lasting snow cover and early snowfalls in autumn or often in the summer, caused the extinction of cattle grazed in the Tatras. As a result of sudden frosts and snowstorms in summer and early autumn even the shepherds froze in mountain meadows. With crop yield deficiency, famine and various pestilences or epidemics spread widely. Many people were forced to emigrate "for food" (Krzemieniowski, 1903; Siemionow, 1992).

\section{Conclusions}

The use of the term LIA is restricted in this study to a period marked by specific climatic conditions, because of lack of glacier cover in the Tatra Mountains since $8.5 \mathrm{ka} \mathrm{BP}$. Evaluation of recent proxy climate reconstructions is based on dendroclimatic data. For reconstructions of summer temperature, the instrumental data for the upper timberline (Hala Gąsienicowa station) were correlated with tree-ring data bank of the period 1550 to 2016. Large similarity in the long-term variability of temperature is also observed in other mountain massifs in Central Europe.

According to the authors the term (LIA) in the Tatras refers to climatic changes characterized by cool rainy seasons (mainly by cold and rainy summers) and related to them intensified morphogenetic processes. Both long cool and warm periods were separated by numerous minor fluctuations. 
Inferring from the reconstructed summer temperature, it was assumed that the LIA began around 1576 and ended in 1895. The coolest periods were between 1576-1675 and 1793-1895, especially the cool decade of 1831-1840.

Based on lichenometrical dating of debris slopes, several phases of intensified activity of debris flows have been identified. The highest activity was noticed in the years 1820-1830, 1850-1860, 1880-1900, and 1910-1920. Making use of these data the end of the LIA in the Tatras can be attributed to the second half of the 20th century. Unfortunately the start date of the LIA is difficult to be determined due to limited time span of lichenometric dating.

Although during the LIA the Tatras were named Snow Mountains, fully developed glaciers were not regenerated. The existing glacierettes reacted to the climate change mainly by increasing their thicknesses. The period of the largest thickness was observed about mid-19th century and, considering a response time, it coincided with the largest extents of Alpine glaciers. During the LIA new rock glaciers had not formed in the Tatras while the existing ones did not show any activity. Due to low temperature of summer seasons the permafrost was likely to expand in the LIA.

Based on the response of glacierettes or cave ice it is not possible to date the onset of the LIA in the Tatras but the date of its end can be attributed to the 1920s.

According to the lake sediments analyses the LIA started about 1400 and ended about 1869 , and was characterized by a large input of mineral materials, mostly coarse ones, delivered to lakes by high-energy geomorphic processes (e.g. debris flows, snow avalanches). After 1860, the lake sediments with a high content of mineral material were sometimes present, as evidenced in the first and second decades as well as in the seventies of the $20^{\text {th }}$ century.

The upper forest line in the Tatras is rising, yet its rise likely is not related to climate warming after the LIA, but it is rather associated with impact of man who intensively exploited the Tatric forest in previous centuries. The LIA, in addition to the increased intensity of morphogenetic processes, affected the lives of inhabitants of this part of the Carpathians. Unfortunately, for humans these changes were very unfavourable because they were characterized by a shortened vegetation period and crop yield deficiency that fostered the spread famine, various epidemics and stimulated migration of people.

The data discussed here on the dynamics of the abiotic environment transformation evidence the view that outstanding climatic, hydrologic and geomorphologic events coincide with the changes observed in other mountain regions of the world. Explicit, precise determination of the LIA duration in the Tatras is not possible. Depending on the adopted criteria the limits of the onset and ending of the LIA vary somehow.

The task ahead is to develop new multi-proxy climate records for a whole Tatra Mountains and surroundings. Works on sediment delivery controls and the relationships between extreme weather and morphodynamic events are needed for both $\mathrm{N}$ - and S-facing sides of the Tatra Mountains. 


\section{Acknowledgments}

Prof. Taduesz Niedźwiedź is sincerely acknowledged for making valuable material available to the Authors that significantly contributed to knowledge on the Little Ice Age in the Tatras.

\section{References}

Atlas of the Tatra Mountains, Abiotic Nature 2015. Tatrzański Park Narodowy, Zakopane.

Bachman, C.R. 1979. Glaciers des Alpes. Bibliothèque des Arts, Paris, 320 pp.

Baranowski, J., Kędzia, S. 2010. Wpływ rzeźby terenu na topoklimat i położenie górnej granicy lasu. In: A. Kotarba (Ed.), Nauka a zarzqdzanie obszarem Tatr i ich otoczeniem. T. 1. Nauki o Ziemi. Materiały IV Konferencji „Przyroda Tatrzańskiego Parku Narodowego a człowiek”, Zakopane, 14-16 października 2010, Zakopane, Tatrzański Park Narodowy, pp. 17-22.

Baumgart-Kotarba, M., Jonasson, C., Kotarba, A. 1990. Studies of youngest lacustrine sediments in the High Tatra Mountains, Poland. Studia Geomorphologica Carpatho-Balcanica 24, 161-177.

Baumgart-Kotarba, M., Kotarba, A. 1995. High mountain environment of the Tatras in the period of Pleistocene and Holocene transition. Biuletyn Peryglacjalny 34, 37-51.

Baumgart-Kotarba, M., Kotarba, A. 2001a. Deglacjacja Doliny Suchej Wody w Tatrach Wysokich. In A. Karczewski, Z. Zwoliński (Eds.), Funkcjonowanie geoekosystemów w zróżnicowanych warunkach morfoklimatycznych - monitoring, ochrona, edukacja. Stowarzyszenie Geomorfologów Polskich, Poznań, pp. 73-84.

Baumgart-Kotarba, M., Kotarba, A. 2001b. Deglaciation in the Sucha Woda and Pańszczyca valleys in the Polish High Tatras. Studia Geomorphologica Carpatho-Balcanica 35, 7-38.

Bednarz,Z. 1984. The comparison of dendroclimatological reconstructions of summer temperature from the Alps and Tatra Mountains from 1741-1965. Dendrochronologia 2, 63-72.

Briffa, K.R., Jones, P.D., Schweingruber, F.H., Osborn, T.J. 1998. Influence of volcanic eruptions on Northern Hemisphere summer temperature over the past 600 years. Nature 393, 450-455. https://doi.org/10.1038/30943.

Ciepły, M., 2011. Dynamika i przyczyny ruchu formy gruzowej w Świstówce Roztockiej. In: R. Machowski, M.A. Rzętała (Eds.), Z badań nad wpływem antropopresji na środowisko. Studenckie Koło Naukowe Geografów UŚ, Sosnowiec 12, pp. 9-18.

Dec, J., Dobiński, W. 1997. Preliminary results of a seismic refraction survey on Hruby Piarg in the Five Polish Lake Valley, Tatra Mountains, Southern Poland. Wyprawy Geograficzne na Spitsbergen, UMCS Lublin, 69-76.

Dobiński, W. 1997. Warunki występowania zmarzliny w alpejskim piętrze Tatr Wysokich. Uniwersytet Śląski, Sosnowiec, 169 pp.

Dobiński, W. 2011. Wieloletnia zmarzlina w wybranych obszarach Tatr, Gór Skandynawskich i Spitsbergenu w świetle kompleksowych badań geofizycznych i analiz klimatologicznych. Wydawnictwo Uniwersytetu Śląskiego, Katowice, 172 pp.

Dzierżek, J., Lindner, L., Nitychoruk, J. 1987. Rzeźba i osady czwartorzędowe Doliny Pięciu Stawów Polskich (Wysokie Tatry). Przegląd Geologiczny 1, 8-15.

Dzierżek, J., Nitychoruk, J. 1986. Types of Fossil Rock Glaciers in the Polish High Tatra Mts. Bulletin of the Polish Academy of Sciences, Earth Sciences 34 (4), 409-418.

Gadomski, A. 1926a. Glacial morphology of the northern slopes of the High Tatras. Nakład B. Kotuli, Cieszyn, 140 pp.

Gadomski, A. 1926b. Na płatach lodowych w Tatrach. Wierchy 4, 31-36. 
Gądek, B. 2002. Obieg masy Lodowczyka Mięguszowieckiego w latach 1998-1999. In: W. Borowiec, A. Kotarba, A. Kownacki, Z. Krzan, Z. Mirek (Eds.), Przemiany środowiska przyrodniczego Tatr, Tatrzański Park Narodowy, Polskie Towarzystwo Przyjaciół Nauk o Ziemi, Oddział Kraków, Kraków-Zakopane, pp. 71-75.

Gądek, B., Grabiec, M. 2008. Glacial ice and permafrost distribution in the Medena Kotlina (Slovak Tatras): Mapped with application of GPR and GST measurements. Studia Geomorphologica Carpatho-Balcanica 42, 5-22.

Gądek, B., Grabiec, M., Kędzia, S., Rączkowska Z. 2016. Reflection of climate changes in the structure and morphodynamics of talus slopes (the Tatra Mountains, Poland). Geomorphology 263, 39-49. https://doi.org/10.1016/J.geomorph.2016.03.024.

Gądek, B., Kędzia, S. 2008. Winter ground surface temperature regimes in the zone of sporadic discontinuous permafrost, Tatra Mountains (Poland and Slovakia). Permafrost and Periglacial Processes 19 (3), 315-321. https://doi.org/10.1002/ppp.623.

Gądek, B., Kędzia, S. 2009. Problemy detekcji wieloletniej zmarzliny na podstawie temperatury u spągu zimowej pokrywy śnieżnej na przykładzie Tatr. Przegląd Geograficzny 81,1, 75-91. https://doi.org/10.7163/PrzG.2009.4.3.

Gądek, B., Rączkowska, Z., Żogała, B., 2009. Derbis slope morphodynamics as a permafrost indicator in the zone of sporadic permafrost, High Tatras, Slovakia. Zeitschrift für Geomorphologie 53 (2), 79-100. https://doi.org/10.1127/0372-8854/2009/0053S3-0079.

Haeberli, W., Hoelzle, M. 1995. Application of inventory data for estimating characteristics of regional climate-change effect on mountain glaciers: a pilot study with the European Alps. Annales of Glaciology 21, 20-212. https://doi.org/101017/S0260305500015834.

Hess, M. 1965. Piętra klimatyczne w polskich Karpatach Zachodnich. Zeszyty Naukowe UJ, Prace Geograficzne 11, 1-267.

Jahn, A. 1958. Mikrorelief peryglacjalny Tatr i Babiej Góry. Biuletyn Peryglacjalny 6, 57-80.

Jania, J. 1997. The problem of Holocene glacier and snow patches fluctuations in the Tatra Mountains: a short report. Glacier fluctuations during the Holocene, Strasbourg, pp. 85-93.

Jonasson, C. 1991. Holocene slope processes of periglacial mountain areas in Scandinavia and Poland. UNGI Raport 79, 1-156.

Jones, P.D., Bradley, R.S. 1992. Climatic variation over the last 500 years, summary. Climate Since A.D. 1500. Routledge, pp. 649-665.

Kaszowski, L., Krzemień, K., Libelt, P. 1988. Postglacjalne modelowanie cyrków lodowcowych w Tatrach Zachodnich. Zeszyty Naukowe Uniwersytetu Jagiellońskiego, Prace Geograficzne 71, 121-142.

Kędzia, S. 1993. The climatic conditions of snow patches in the Tatra Mountains as an example glacieret in the Kocioł Mięguszowiecki. Uniwersytet Jagielloński, Zakład Klimatologii Instytutu Geografii, Kraków: 69 pp.

Kędzia, S. 2004. Klimatyczne i topograficzne uwarunkowania występowania wielo letniej zmarzliny w Tatrach Wysokich (na przykładzie Koziej Dolinki), Instytut Geografii $i$ Przestrzennego Zagospodarowania Polskiej Akademii Nauk, Warszawa, 124 pp.

Kędzia, S. 2010. The age of debris surfaces on the Żółta Turnia Peak (the Polish Tatra Mts.). Geomorphologia Slovaca et Bohemica 10 (2), 29-38.

Kędzia, S.2014. Are there any active rock glaciers in the Tatra Mountains? Studia Geomorphologica Carpatho-Balcanica 48, 5-16. https://doi.org/10.1515/sgcb-2015-0001.

Kędzia, S. 2015. The occurrence of glaciers in the Polish Tatra Mountains during the Little Ice Age. Zeitschrift für Geomorphologie 59 (2), 229-241. https://doi.org/10.1127/zfg/2014/0150.

Kędzia, S., Mościcki, J., Wróbel, A. 1998. Studies on the occurence of permafrost in Kozia Valley (The High Tatra Mts). In: J. Repelewska-Pękalowa (Ed.), Relief, Quaternary palaeogeography and changes of the polar environment. Polar session, IV Conference of 
Polish Geomorpologists, Lublin, 3-6 June 1998, Spitsbergen Geographical Expeditions, Maria Curie-Skłodowska University Press, Lublin, pp. 51-57.

Kędzia, S., Kotarba, A., Mościcki, J. 2004. Lodowiec gruzowy nad Wielkim Hińczowym Stawem w Tatrach Słowackich - wyniki wstępnych badań termicznych. In: A. Styczyńska, A.A. Marsz (Eds.), XXX Międzynarodowe Sympozjum Polarne. Gdynia. Akademia Morska, Polish Polar Studies, pp. 167-177.

Klimaszewski,M. 1948. Polskie Karpaty Zachodnie w okresie dyluwialnym. Prace Wrocławskiego Towarzystwa Naukowego, B, 7, 236 pp.

Klimaszewski, M. 1988. Rzeźba Tatr Polskich. PWN. Warszawa, 709 pp.

Kłapyta, P. 2011. Relative Surface Dating of Rock Glacier Systems in the Žiarska Valley, the Western Tatra Mountains. Slovakia. Studia Geomorphologica Carpatho-Balcanica 45, 89106.

Kłapyta, P. 2013. Application of Schmidt hammer relative age dating to Late Pleistocene moraines and rock glaciers in the Western Tatra Mountains. Slovakia. Catena 111, 104-121. https://doi. org/10.1016/j.catena.2013.07.004.

Kotarba, A. 1986. Lodowce gruzowe w Tatrach. Wszechświat, 87, 5, 97-99.

Kotarba, A. 1988. Fossil rock glaciers in the Polish Tatra Mountains: origin and age. In: M. Pecsi, L. Starkel (Eds.), Paleography of Carpathian Regions. Geographical Research Institute Hungarian Academy of Science, Budapeszt, pp. 161-169.

Kotarba, A. 1989. On the age of debris slopes in the Tatra Mountains. Studia Geomorphologica Carpatho-Balcanica 23, 139-152.

Kotarba, A. 1991-1992. Reliktowe lodowce gruzowe jako element deglacjacji Tatr Wysokich. Studia Geomorphologica Carpatho-Balcanica 25-26, 133-150.

Kotarba, A. 1992. Denudacja mechaniczna Tatr Wysokich pod wpływem opadów ulewnych. Prace Geograficzne IG i PZ PAN 155, 191-208.

Kotarba, A. 1995. Rapid mass wasting over the last 500 years in the High Tatra Mountains. Quaestiones Geographicae, Special Issue 4, 177-183.

Kotarba, A. 2004. Zdarzenia geomorfologiczne w Tatrach Wysokich podczas małej epoki lodowej. Prace Geograficzne IG i PZ PAN 197, 9-55.

Kotarba, A., Kaszowski, L., Krzemień, K. 1987. High-mountain denudational system of the Polish Tatra Mountains. Geographical Studies, Special Issue 3, 1-106.

Kotarba, A., Łokas, E., Wachniew, P. 2002. ${ }^{210} \mathrm{~Pb}$ dating of young Holocene sediments in highmountain lakes of the Tatra Mountains. Geochronometria 21, 197-208.

Kotarba, A., Starkel, L. 1972. Holocene morphogenetic altitudinal zones in the Carpathians. Studia Geomorphologica Carpatho-Balcanica 6, 21-35.

Kotarba, A., Strömquist, L. 1984. Transport, sorting and deposition processes of alpine debris slope deposits in the Polish Tatra Mountains. Geografiska Annaler 66A, 285-294. https:// doi.org/10.2307/520851.

Krzemieniowski, S. 1903. Łąki i pastwiska w Tatrach. Sprawozdania Komisji Fizjograficznej 1902, Kraków, 207-215.

Lamb, H.H. 1977. Climate: present, past and future. vol.2. Climate history and the future. Methuen, London, $835 \mathrm{pp}$.

Lindner, L., Dzierżek, J., Marciniak, B., Nitychoruk, J. 2003. Outline of Quaternary glaciations in the Tatra Mountains: their development, age and limits. Geological Quarterly 47 (3), 269-280.

Lovell, T.V. 2000. As climate changes, so do glaciers. Proceedings of the National Academy of Science USA 97, 1351-1354. https://doi.org/10.1073/pnas.97.4.1351.

Luckman, B.H. 2000. The Little Ice Age in the Canadian Rockies. Geomorphology, 357-384. https://doi.org/10.1016/S0169-555X(99)00104-X. 
Lukniš, M. 1973. Relief Vysokych Tatier a ich predpolia. VEDA, Bratislava, 446 pp.

Ładygin, Z. 2008. Pasterstwo. Wydawnictwa Tatrzańskiego Parku Narodowego, Zakopane, 6 pp.

Makos, M. 2015. Deglaciation of the High Tatra Mountains. Cuadernos de Investigación Geográfica 41 (2), 317-335. https://doi.org/10.18172/cig.2697.

Maruszczak, H. 1999. Trends to climate change in the last millennium. In: L. Starkel (Ed.), Geografia Polski - Środowisko Przyrodnicze. Wydawnictwo Naukowe PWN, Warszawa, pp. 180-188.

Matthes, F. 1939. Report of Committee on Glaciers. Transactions American Geophysical Union 20, 518-523. https://doi.org/10.1029/TR020i004p00518.

Midriak, R. 1985. Debris flows and their occurrence in the Czechoslovak high-mountain West Carpathians. Proceedings International Symposium on Erosion, Debris Flow and Disaster Prevention, September 3-5, 1985, Tsukuba, Japan, pp. 175-180.

Mościcki, W.J. 2010. Temperatura na NE stoku Świnicy i w Koziej Dolince w Tatrach w okresie 2007-2009. In: A. Kotarba (Ed.), Przyroda Tatrzańskiego Parku Narodowego a Człowiek, Nauki o Ziemi, 1, Wydawnictwa Tatrzańskiego Parku Narodowego, Zakopane, pp. 95-102.

Mościcki, J.W., Kędzia, S. 2001. Investigation of mountain permafrost in the Kozia Dolinka valley, Tatra Mountains, Poland, Norsk Geografisk Tidsskrift 55, 235-240. https://doi. org/10.1080/00291950152746586.

Nemčok, A., Mahr, T. 1974. Kamenné Ladovce v Tatrách. Geografický časopis 26, 4, 359-374.

Niedźwiedź, T. 2003. Extreme precipitation events on the northern side of the Tatra Mountains. Geographia Polonica 76, 2, 15-23.

Niedźwiedź, T., 2004. Rekonstrukcja warunków termicznych lata w Tatrach od roku 1550. Prace Geograficzne IG i PZ PAN 197, 57-88.

Röthlisberger, F., Haas, P., Holzhauser, H., Keller, W., Bircher, W., Renner, F. 1980. Radiocarbon dating of fossil soils (fAh) and woods from moraines and glaciers in the Alps. Geography in Switzerland. Geographica Helvetica 35(5), 21-52

Siarzewski, W. 1996. Jaskinie lodowe w Tatrach Polskich. In: A. Kotarba (Ed.), Przyroda Tatrzańskiego Parku Narodowego a Człowiek, 1, Tatrzański Park Narodowy, Polskie Towarzystwo Przyjaciół Nauk o Ziemi, Kraków - Zakopane, pp. 98-101.

Siemionow, A. 1992. To i owo o Tatrach. Tom I, Ciekawostki fizjograficzne z dziedziny ekstremaliów morfologicznych i geologicznych, zjawisk meteorologicznych, optycznych, flory i fauny Tatr. Bibliografia Tatrzańsko-Zakopiańska z Kozicq, Kalwaria Zebrzydowska, $160 \mathrm{pp}$.

Sokołowski, M. 1928. O górnej granicy lasu w Tatrach. Zakład Badań Drzew i Lasu 1. Zakłady Kórnickie, Kraków.

Sokołowski, S. 1936. Las tatrzański. Z Tatr i Podhala 2, Nasza Księgarnia, Warszawa, 136 pp.

Szaflarski, J. 1972. Poznanie Tatr. Szkice z rozwoju wiedzy o Tatrach do połowy XIX wieku. Sport i Turystyka, Warszawa, $620 \mathrm{pp}$.

Troll, C. 1972. Geoecology and the word-wide differentiation of high-mountain ecosystems. In C. Troll (ed.) Geoecology of the high-mountain regions of Eurasia, Proceedings of the symposium of IGU Commission of High Altitude Geoecoloogy, November 20-22, 1969 at Mainz, Franz Steiner Verlag, Wiesbaden, pp. 1-16.

Vivian, R. 1975. Les glaciers des Alpes Occidentales. Imprimerie Allier, Grenoble, 513 pp.

Wdowiak, S. 1961. Współczesny lodowiec karowy w Wielkim Kotle Mięguszowieckim nad Morskim Okiem w Tatrach. Biuletyn Geologiczny 1(1), 87-92.

Wiśliński, A. 2002. Abort changes within some firn and ice patches in the Morskie Oko basin. In: W. Borowiec, A. Kotarba, A. Kownacki, Z. Krzan, Z. Mirek (Eds.), Przemiany Środowiska Przyrodniczego Tatr. Tatrzański Park Narodowy, Polskie Towarzystwo Przyjaciół Nauk o Ziemi, Oddział Kraków, Kraków-Zakopane, pp. 71-75. 
Zasadni, J., Kłapyta, P. 2009. An attempt to asses the modern and Little Ice Age climatic snowline altitude in the Tatra Mountains. Landform Analysis 10, 124-133.

Zielski, A., Krąpiec, M. 2004. Dendrochronologia. PWN, Warszawa, 328 pp.

Zumbühl, H. J., Messerli, B., Pfister, C. 1983. Die Kleine Eiszet. Gletschergeschichte im Spiegel der Kunst. Gletschergarten-Museum Luzern, Schweizerisches Alpines Museum Bern, 60 pp.

Zwoliński, S. 1961. W podziemiach tatrzańskich. Wydawnictwa Geologiczne, Warszawa, 251 pp. 